\title{
Development of Liposome-Based Immunoassay for the Detection of Cardiac Troponin I
}

\author{
Remya Radha and Mohammad Hussein Al-Sayah *(D) \\ Department of Biology, Chemistry, and Environmental Sciences, American University of Sharjah, \\ Sharjah 26666, United Arab Emirates; rradha@aus.edu \\ * Correspondence: malsayah@aus.edu
}

check for

updates

Citation: Radha, R.; Al-Sayah, M.H. Development of Liposome-Based Immunoassay for the Detection of Cardiac Troponin I. Molecules 2021, 26, 6988. https://doi.org/10.3390/ molecules 26226988

Academic Editors: Sofia Azeredo Pereira, Judit Morello, Alexandra Maria Moita Antunes and Iwona Cicha

Received: 28 September 2021 Accepted: 16 November 2021 Published: 19 November 2021

Publisher's Note: MDPI stays neutral with regard to jurisdictional claims in published maps and institutional affiliations.

Copyright: (c) 2021 by the authors. Licensee MDPI, Basel, Switzerland. This article is an open access article distributed under the terms and conditions of the Creative Commons Attribution (CC BY) license (https:/ / creativecommons.org/licenses/by/ $4.0 /)$.

\begin{abstract}
Cardiovascular diseases (CVDs) are one of the foremost causes of mortality in intensive care units worldwide. The development of a rapid method to quantify cardiac troponin I (cTnI) — the goldstandard biomarker of myocardial infarction (MI) (or "heart attack")—becomes crucial in the early diagnosis and treatment of myocardial infarction (MI). This study investigates the development of an efficient fluorescent "sandwich" immunoassay using liposome-based fluorescent signal amplification and thereby enables the sensing and quantification of serum-cTnI at a concentration relevant to clinical settings. The calcein-loaded liposomes were utilized as fluorescent nano vehicles, and these have exhibited appropriate stability and efficient fluorescent properties. The standardized assay was sensitive and selective towards cTnI in both physiological buffer solutions and spiked human serum samples. The novel assay presented noble analytical results with sound dynamic linearity over a wide concentration range of 0 to $320 \mathrm{ng} / \mathrm{mL}$ and a detection limit of $6.5 \mathrm{ng} / \mathrm{mL}$ for cTnI in the spiked human serum.
\end{abstract}

Keywords: myocardial infarction; cardiac troponin; cTnI-detection; calcein liposomes; fluorescence; signal quantification

\section{Introduction}

Among the non-communicable diseases, cardiovascular diseases (CVDs) are among the leading causes of death in developing countries, including Mediterranean and Gulf Cooperation Council (GCC) regions [1-3]. The World Health Organization (WHO) cautioned on the high CVDs-related mortality of more than 23.6 million people by the year 2030 [4]. The fatty deposits and blockage of arteries lead to deadly acute myocardial infarction (MI), or heart attack, and the diagnosis for MI fails if the patients are asymptomatic, without chest pain or shortness of breath. Since there is no single diagnostic tool available for MI detection, diagnosis follows a regular clinical collection of the patient's medical history, physical check-ups, and clinical testing [1,5]. Electrocardiography (ECG) is a common tool for the initial evaluation and spotting of MI patients; however, more than $40 \%$ of the cases show a normal ECG profile while testing [6,7]. Hence, worldwide research attention has moved to the measurement of certain biomarkers in the patient's blood that could provide an accurate diagnosis of MI [8].

Troponin is a complex of three proteins (Troponin I (TnI), Troponin C (TnC), and Troponin $\mathrm{T}(\mathrm{TnT})$ ) that regulate the contraction of the skeletal and cardiac muscles. The cardiac forms of TnI and TnT are released from myocardial cells during necrosis or cell death [9]. As cTnI is confined inside the heart muscle, its specificity towards MI detection stands significantly higher compared to other heart biomarkers [10]. In the event of MI, cTnI and cTnT are released from the injured heart muscles into the bloodstream and their concentration remains high over several days, even when no other symptoms of MI are present $[11,12]$. The normal concentration of cTnI is $1-2 \mathrm{ng} / \mathrm{mL}$ or less; after the onset of MI, the concentration of cTnI increases to about $50 \mathrm{ng} / \mathrm{mL}$ within 3-6 h, reaching as high as $500 \mathrm{ng} / \mathrm{mL}[13,14]$. The precise quantification of the blood-cTn levels in a patient 
with ischemia/chest pain indicates whether the patient had a myocardial infarction (MI) or not $[15,16]$. In fact, troponin time curves indicate that the peak elevation of cTnI in the patient's blood reflects the time and the magnitude of the MI $[17,18]$. For a small MI, the elevation peaks within 18 to $24 \mathrm{~h}$ and goes back to near normal within a couple of days, while, for a medium MI, a higher peak of $\mathrm{cTnI}$ is expected within 24 to $36 \mathrm{~h}$ and it will take more than five days to go to near normal levels. A much higher peak is expected for a strong MI within 36 to $48 \mathrm{~h}$ and it will take more than a week to reach near normal levels $[17,18]$. However, it should be noted that the temporary elevation of cTnI was also reported in cases of non-cardiac conditions, such as exercise-induced elevation [19,20], non-coronary diseases [21], chronic kidney diseases [22], critical illness pulmonary embolism, sepsis, and stroke [23]. Therefore, while the cTnI level is an important marker for the diagnosis of MI, considering other physical symptoms and the medical history of the patient are essential elements of good clinical practice.

Over the last couple of decades, the use of immunoassays for clinical and research purposes has gained remarkable attention due to their ability to accurately detect specific antigen or antibody molecules within a short span of time. There are different strategies used for the development of immunoassays; however, the "sandwich" immunoassay is one of the most reported assay designs for the detection of $\mathrm{cTnI}$ in the last few years $[13,15,24-26]$. This assay design is based on capturing the targeted antigen between a "capture" antibody and a "detecting" antibody where each binds at a different and a distant epitope. The capturing antibody is usually immobilized on a surface, while the detecting antibody is associated with the signaling mechanism and signal amplification of the detection process. Different signaling mechanisms have been reported, and these include optical (colorimetric, fluorescence, emission), electrochemical, and magnetic signals, in addition to radioactivity and surface plasmon resonance (SPR) [13,27-42]. Yet, many of these assay types require lab settings with large equipment and lengthy procedures, limiting their use at point of care. In addition, many of these assays suffer from either low sensitivity or a narrow range of detection, which limits their application in clinical settings.

Therefore, this paper reports the development of a novel liposome-based signal amplification fluorescent immunoassay for the detection and quantification of cTnI. The approach of this study is based on a fluorescent sandwiched immunoassay (Scheme 1, Step A to Step G) for capturing cTnI between a surface-immobilized capturing antibody and a biotin-conjugated secondary antibody (detection antibody). The detection of the captured biomarker is then achieved via a biotin-conjugated liposome through a streptavidin (SA) intermediate. The liposome acts as the nanocarrier for a load of a fluorescent dye (calcein), which is released upon the lysing of the liposome with Triton X-100 [43,44]. The intensity of the emission signal is dependent on the concentration of the cTnI in the sample. 


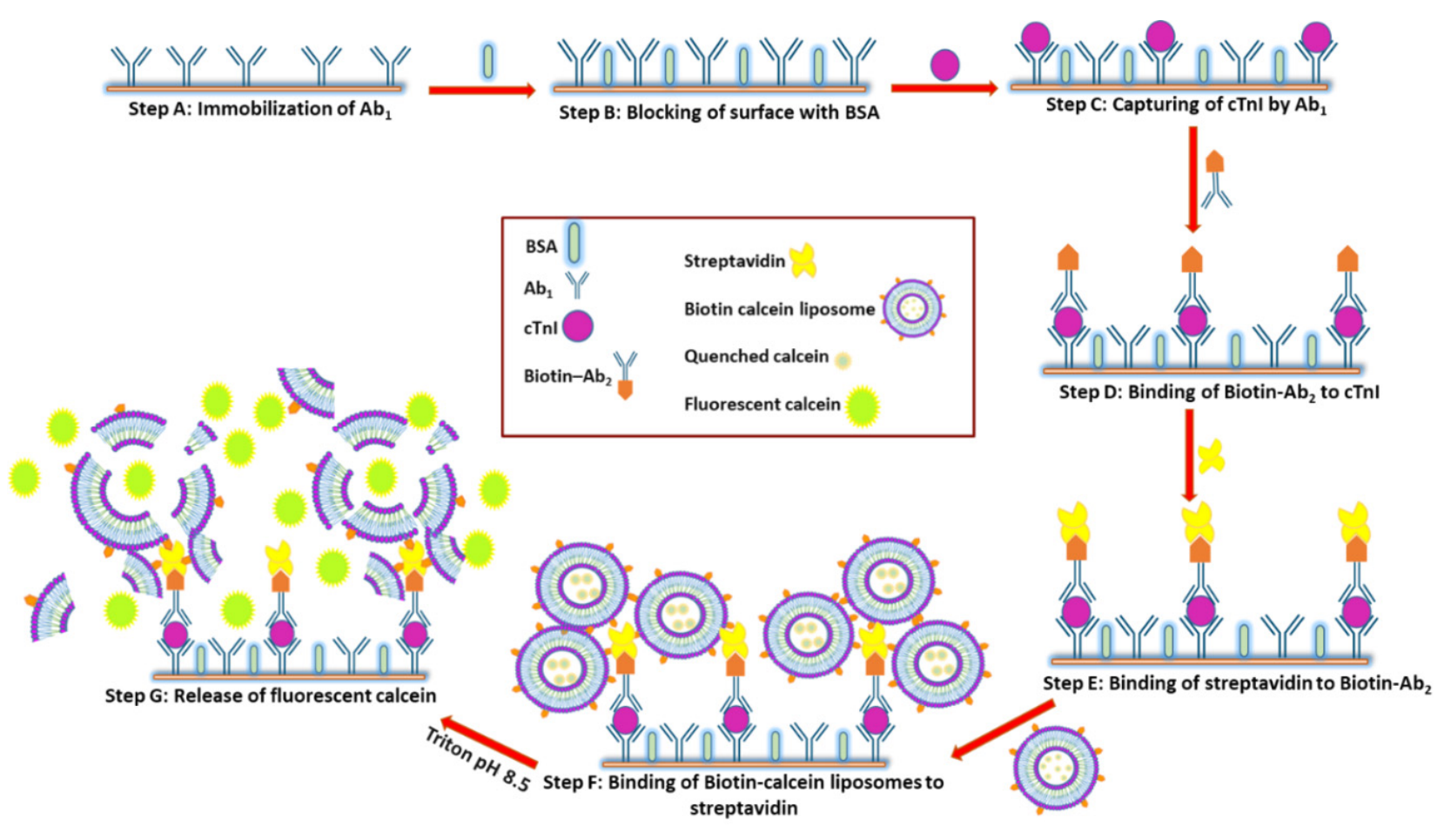

Scheme 1. Schematic illustration of cTnI detection via liposome-based fluorescent immunoassay.

\section{Results and Discussion}

\subsection{Characterization and Stability Analysis on Biotin-Calcein Liposomes}

Liposomes are non-toxic, biocompatible nano-vehicles formed by the self-assembly of phospholipids into a bilayer, creating an inside aqueous compartment that can be loaded with water-soluble compounds, such as fluorescent dyes (Scheme 1). The outside layer of the phospholipid can be chemically functionalized to be brandished with different moieties, such as ligands or antibodies [45-49]. On the other hand, calcein is a watersoluble fluorescent dye that has a self-quenching property at high concentrations, and it can be loaded inside liposomes at high concentrations $[46,50]$. The exposure of liposomes to mechanical stress, such as ultrasound waves, or to lysing detergents (Triton X-100), leads to the disintegration of the lipid bilayer and thereby releases the components from the internal compartment of the liposomes [50]. The release of calcein from liposomes in such conditions ends self-quenching and induces a strong fluorescence signal.

The liposomes are a crucial component of the developed assay; hence, the preparation and characterization procedures of these nanocarriers are essential to ensure efficacy and reproducibility. Biotin-conjugated calcein-loaded liposomes were synthesized via the thin-film hydration method, similar to the previously reported studies $[45,51]$, and a full characterization process was applied, including a Stewart assay, to quantify the total lipid concentration of the liposome solution, DSL measurements, and stability studies. The Stewart assay was conducted according to previously reported procedures [51], indicating a calculated total lipid concentration of $10.1 \mathrm{mmol} / \mathrm{L}$. In addition, dynamic light scattering (DLS) studies revealed the size range and \% polydispersity (Pd) of the liposomes (Figure 1). The obtained Pd index value was found to be acceptable as it falls in the criteria of its upper limit of $20 \%$ for DLS measurements [51]. As shown in Table 1, even after 10 weeks of storage at $4{ }^{\circ} \mathrm{C}$, the liposome solution was found to be stable, with minimal variation in their average radius $(96.3 \pm 3.9 \mathrm{~nm})$, while maintaining a quenched load of calcein that was released upon the addition of Triton X-100, leading to a five-fold increase in the fluorescence signal. 


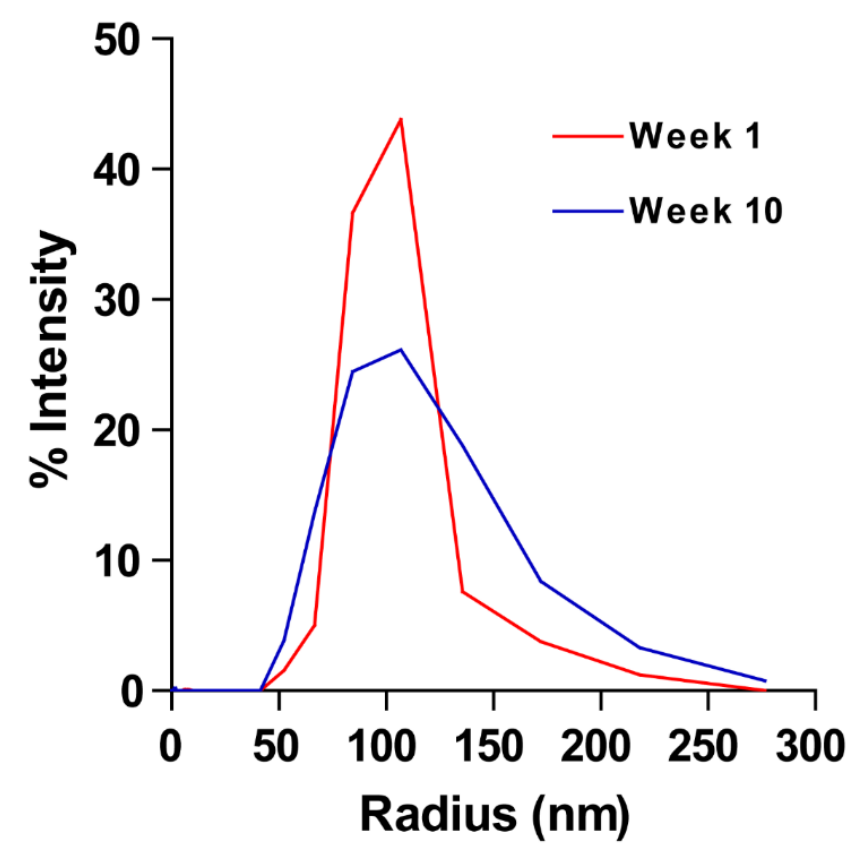

Figure 1. Light-scattering measurements on calcein-loaded liposome. DLS of newly synthesized calcein liposomes and after 10 weeks of storage at $4{ }^{\circ} \mathrm{C}$ of the same batch.

Table 1. Dynamic light scattering measurements of calcein liposomes.

\begin{tabular}{ccc}
\hline Calcein Liposome & Mean Radius $(\mathbf{n m})$ & \%Pd \\
\hline Freshly Synthesized & $98.2 \pm 2.4$ & $12 \pm 3.8$ \\
After 10 weeks & $96.3 \pm 3.9$ & $15.9 \pm 1.5$ \\
\hline
\end{tabular}

Values are the mean of three independent measurements. (Statistical analysis using $t$-test showed insignificant differences between the mean radius values of week 1 and week $10(p>0.05)$ ).

\subsection{Standardization of Immunoassay Parameters}

A series of experiments were carried out to standardize the conditions of the assay and to optimize the parameters, including the combination of capture-detection antibodies, concentration of $\mathrm{Ab}_{1}$, buffer systems (Ab-coating), microplate blocking solution, number of washings in assay steps, assay incubation time, dilutions and concentrations of each assay component, and fluorescence measurement parameters.

\subsubsection{Optimization of Capture Antibody and Detection Antibody Combination}

The binding of the protein by the detection and the capture antibody needs to take place at spatially distant epitopes to minimize the possible steric effect on the binding efficacy. The cTnI protein has 209 amino acid residues with a unique sequence at $\mathrm{N}$-terminal end ( 40 residues) for cTnI over other forms of troponin [52,53]. We have tested three pairs of antibodies specific to different epitopes in order to determine the most efficient combination that provides a strong signal: i) Anti-h cTnI 9701 binds to the epitope at residues 85-95, Anti-h cTnI 9703 recognizes the epitope at residues 39-50, and Anti-h cTnI 9705 binds at $21-30$ residues.

Figure 2 shows a comparison of the relative fluorescence obtained to cTnI levels for the assay trials with the different combinations of $\mathrm{Ab}_{1}-\mathrm{Ab}_{2}(9705-9703,9703-9705$, and 9701-9705). The relative fluorescence was calculated for each data point using the relation $\left(\mathrm{f}-\mathrm{f}_{0}\right) / \mathrm{f}_{0}$, where ' $\mathrm{f}$ ' is the fluorescence emission intensity measured from a well containing a particular cTnI level and ' $\mathrm{f}_{0}$ ' is the same for a well with $0-\mathrm{cTnI}$. Among the three $A b_{1}-\mathrm{Ab}_{2}$ combinations tested, the 9705-9703 antibody combination (Figure 2, red plot) presented a good relative increase in the fluorescence for the $\mathrm{cTnI}$ levels tested. Based on the results, the combination of Anti-h cTnI 9705-9703 was selected as the capture-detection Ab system 
for further assay runs. The choice of 9705 ensures a high specificity for capturing cTnI over other forms of troponin since its epitope lies within the unique $\mathrm{N}$-terminal end of the protein.

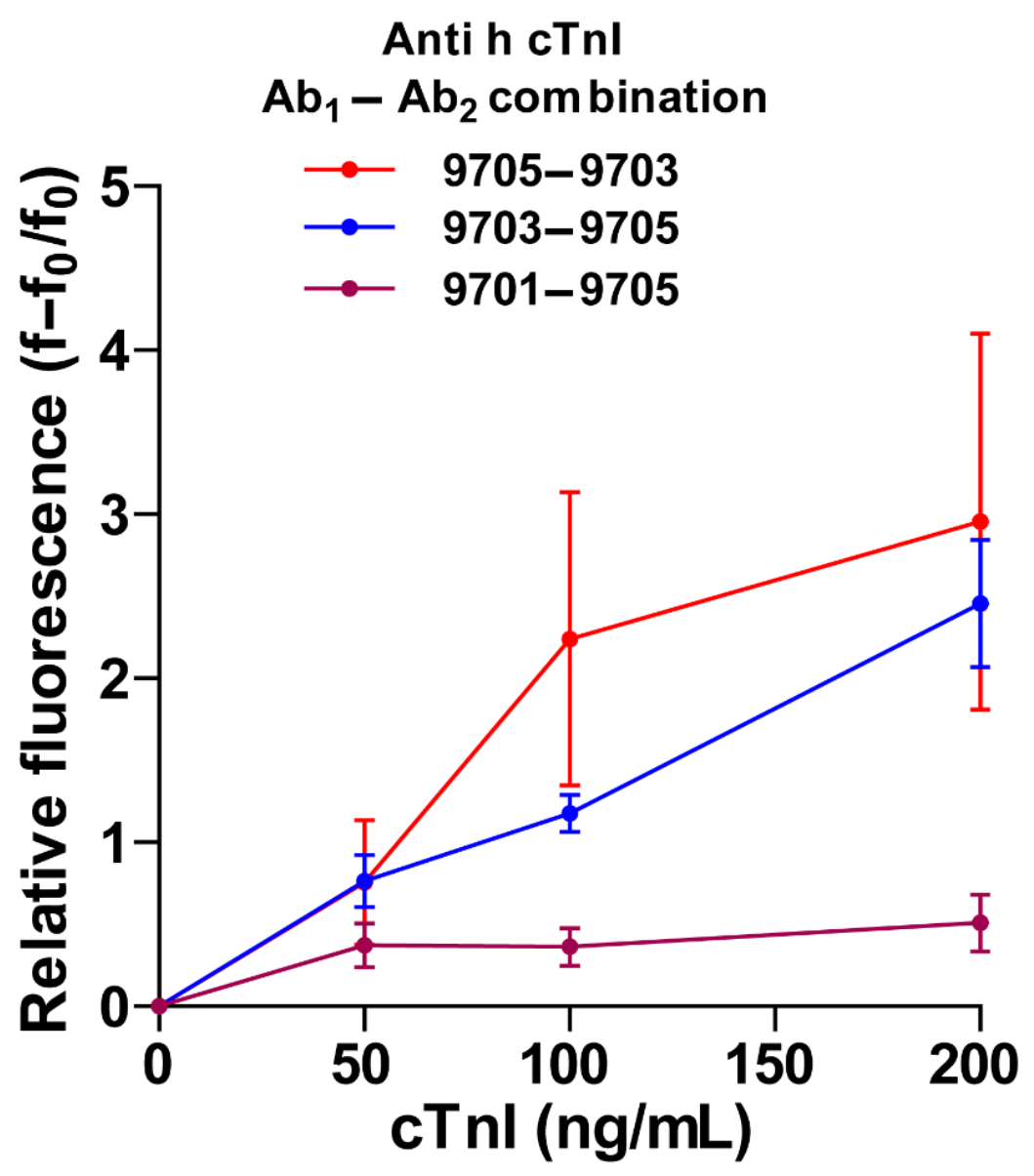

Figure 2. Effect of capture-detection antibody on the assay. The different plots correspond to the change in relative fluorescence over different cTnI levels exhibited by the assays with three different combinations of $A b_{1}-\mathrm{Ab}_{2}$. The assays were performed in 3 batches maintaining the coating concentration as $2 \mu \mathrm{g} / \mathrm{mL}$ with cTnI levels of $0,50,100$, and $200 \mathrm{ng} / \mathrm{mL}$. The experiment used $2 \mu \mathrm{g} / \mathrm{mL}$ of Streptavidin, $2 \mu \mathrm{g} / \mathrm{mL}$ of Biotin- $\mathrm{Ab}_{2}$, and 1:100 diluted biotin calcein liposomes. The error bars show the standard deviation of values for the triplicate readings for three different assay experiments. (Two-way ANOVA test showed that there is statistically significant difference $(p<0.05)$ between 9701-9705 assay and the other two assays ( $p=0.009$ and $p<0.001)$, but there is statistically insignificant difference ( $p=0.446$ ) between 9703-9705 and 9705-9703).

\subsubsection{Effect of Incubation Time}

One of the major hurdles in applying sandwich assays in point-of-care testing is the time required to complete the assay. Thus, we investigated whether the decrease in the incubation time of each assay step to half would affect the efficacy of the assay. We performed assay trials with 9705 as a capture $\mathrm{Ab}_{1}(5 \mu \mathrm{g} / \mathrm{mL})$ using a shorter incubation time of each assay step such that $\mathrm{cTnI}$ and $\mathrm{Ab}_{2}$-biotin were incubated for 30 min while other parameters (Streptavidin (SA), blocking liposome, and calcein liposome) were incubated for $15 \mathrm{~min}$. As depicted in Figure 3, the change in the relative fluorescence of the assay with reduced time presented a very low response and linearity correlation $(y=0.0028 \mathrm{x}$, $\left.\mathrm{R}^{2}=0.56\right)$ to the concentration of $\mathrm{cTnI}$ in solution as compared to the assay with double the incubation time of each step, which exhibited a good linear fit $\left(y=0.0227 x, R^{2}=0.95\right)$. 


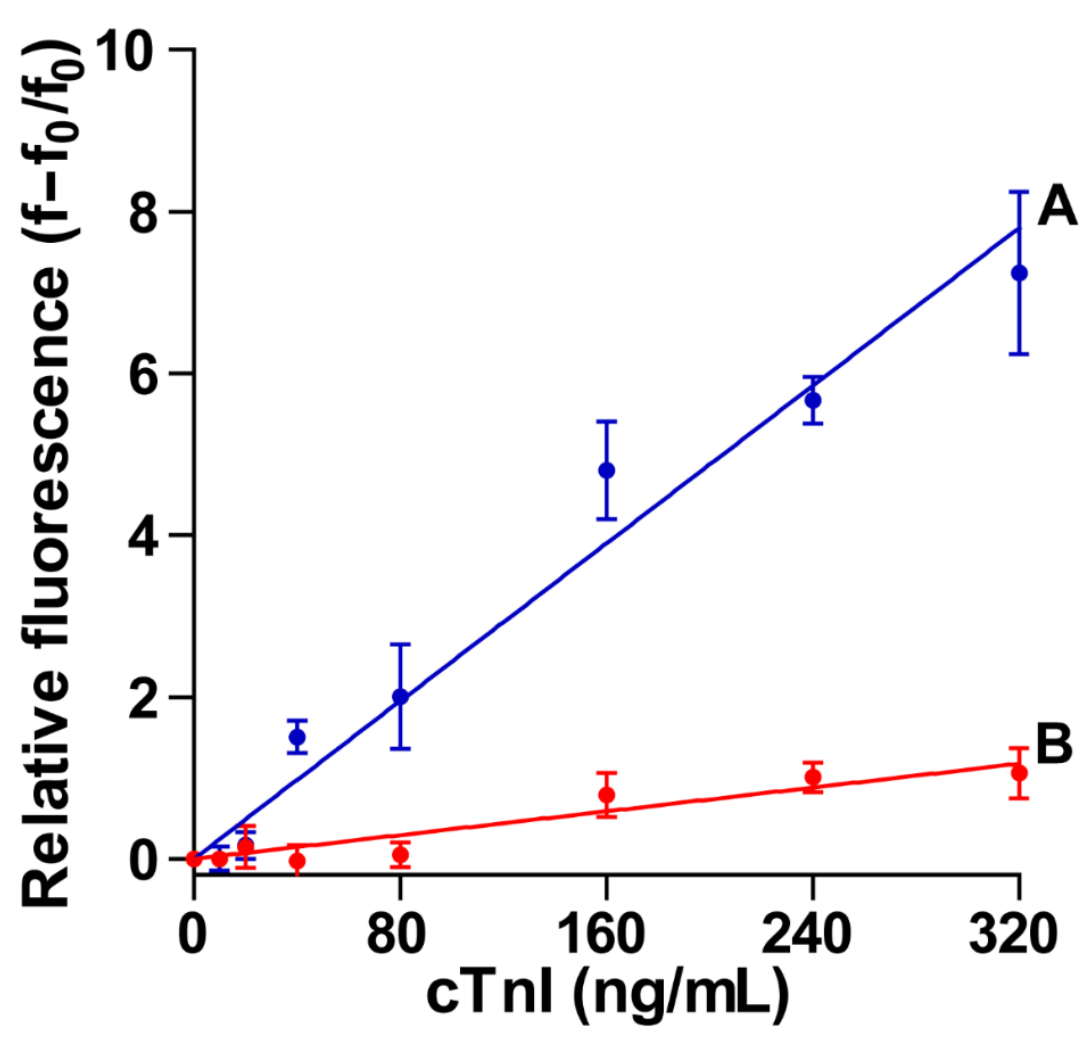

Figure 3. Standardization of assay incubation time. Assay trials were done by varying the incubation time for each step addition; (A) $\mathrm{cTnI}$ and $\mathrm{Ab}_{2}$-biotin for $60 \mathrm{~min}$ and other components (SA and calcein liposome) for $30 \mathrm{~min}$; (B) $\mathrm{cTnI}$ and $\mathrm{Ab}_{2}$-biotin were incubated for $30 \mathrm{~min}$ and other parameters (SA, blocking liposome, and calcein liposome) for $15 \mathrm{~min}$. Less response was observed for B compared to A. Assay conditions used were as follows: coating antibody concentration of $5 \mu \mathrm{g} / \mathrm{mL}$, cTnI levels of 0-320 ng/mL, $2 \mu \mathrm{g} / \mathrm{mL}$ of SA, $2 \mu \mathrm{g} / \mathrm{mL}$ of Biotin- $\mathrm{Ab}_{2}$, and 1:100 diluted biotin calcein liposomes. The error bars show the standard deviation of values for the triplicate readings obtained for three different assay experiments. (Two-way ANOVA test showed that there is statistically significant difference $(p<0.05)$ between A and B assays $(p<0.001)$ and that the change in the relative fluorescence for each assay is significantly dependent (for $\mathrm{A}, p<0.001$; for $\mathrm{B}, p<0.001$ ) on the concentration of cTnI in solution).

\subsubsection{Standardization of Coating Antibody Concentration}

The coating concertation of the capture antibody on the surface can have a detrimental effect on the assay results. A high concentration can lead to the overcrowding of the antibody on the surface and could result in a lower capturing efficacy, while a low concentration could lead to lower sensitivity and a weak signal of the assay. Thus, in order to optimize the coating concentration of the capturing antibody, we selected three concentrations at 2,4 , and $5 \mu \mathrm{g} / \mathrm{mL}$. The assays were then conducted with all the other conditions maintained, and the relative change in fluorescence $\left(f-f_{0} / f_{0}\right)$ was monitored as the concentration cTnI (ng/mL) was increased. It was noted (as depicted in Figure 4) that an $\mathrm{Ab}_{1}$ concentration of $4 \mu \mathrm{g} / \mathrm{mL}$ (green plot) yields the maximum relative fluorescence to the levels of cTnI among the three coating concentrations. 


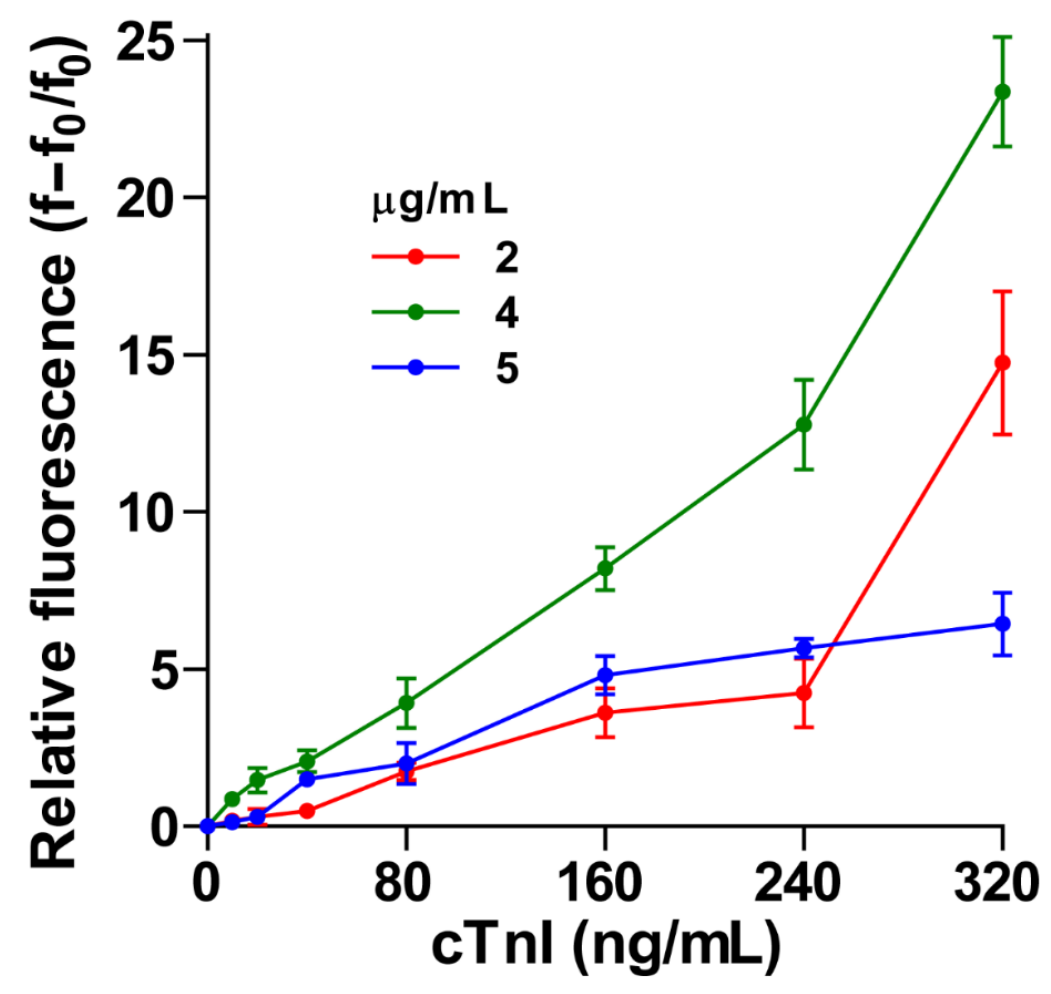

Figure 4. Effect of $\mathrm{Ab}_{1}$ (capture antibody) concentration on cTnI assay. The relative emission at different levels of cTnI is plotted for three different concentrations of capturing antibodies (Anti 97052,4 , and $5 \mu \mathrm{g} / \mathrm{mL}$ ) keeping other assay parameters the same (cTnI levels $0-320 \mathrm{ng} / \mathrm{mL}, 2 \mu \mathrm{g} / \mathrm{mL}$ of $\mathrm{SA}, 2 \mu \mathrm{g} / \mathrm{mL}$ of Biotin- $\mathrm{Ab}_{2}$, and 1:100 diluted biotin calcein liposomes). The error bars show the standard deviation of values for the triplicate readings obtained for three different assay experiments. (Two-way ANOVA test showed that there is statistically significant difference $(p<0.05)$ between 4 assay and the other two assays ( $p<0.001$ and $p<0.001)$, but there is statistically insignificant difference ( $p=0.069$ ) between 2 and 5 assays).

\subsubsection{Effect of Streptavidin Concentration and Liposome Dilution}

The concentrations of the SA and liposomes have a critical and a direct effect on the fluorescence signal of the assay. Too high of a concentration of SA or liposomes can lead to non-specific binding and, hence, a higher fluorescent signal that is not correlated with the concentration of the $\mathrm{cTnI}$ in solution. Thus, we conducted a single batch experiment for a fixed level of cTnI $(80 \mathrm{ng} / \mathrm{mL})$ at varying concentrations of SA $(1,2,4,6$, and $8 \mu \mathrm{g} / \mathrm{mL})$ and calcein-loaded liposome (1:10 and 1:100 dilutions). The observed trend showed no linear correlation of $\left(\mathrm{f}-\mathrm{f}_{0} / \mathrm{f}_{0}\right)$ with the SA concentration or liposome concentration/dilution. Thus, concentrations of SA at $2 \mu \mathrm{g} / \mathrm{mL}$ and liposome dilution at 1:100 were used as the optimized concentration for the standardized assay (Figure 5).

2.2.5. Standardized Assay for the Detection of cTnI Spiked in Bovine Serum Albumin (BSA)/Phosphate Buffer Saline (PBS)

As the variant conditions of the assay were optimized, we conducted the standardized assay in a physiological buffer system (BSA/PBS at pH 7.4) to validate the feasibility of the developed assay before testing the sensitivity towards the $\mathrm{cTnI}$ in the human serum. The cTnI was spiked into the buffer solution at various concentrations, and the assay was conducted at the following optimized conditions:

(i) Concentrations: coating $\mathrm{Ab}_{1}$ concentration-at $4 \mu \mathrm{g} / \mathrm{mL}$, cTnI levels: 0-320 ng/mL, $\mathrm{SA}: 2 \mu \mathrm{g} / \mathrm{mL}$, Biotin- $\mathrm{Ab}_{2}: 2 \mu \mathrm{g} / \mathrm{mL}$, and 1:100 diluted biotin calcein liposomes

(ii) Incubation time: $\mathrm{cTnI}$ and $\mathrm{Ab}_{2}$-biotin for $60 \mathrm{~min}$, $\mathrm{SA}$ and calcein liposome for $30 \mathrm{~min}$, and blocking liposome for $15 \mathrm{~min}$. 


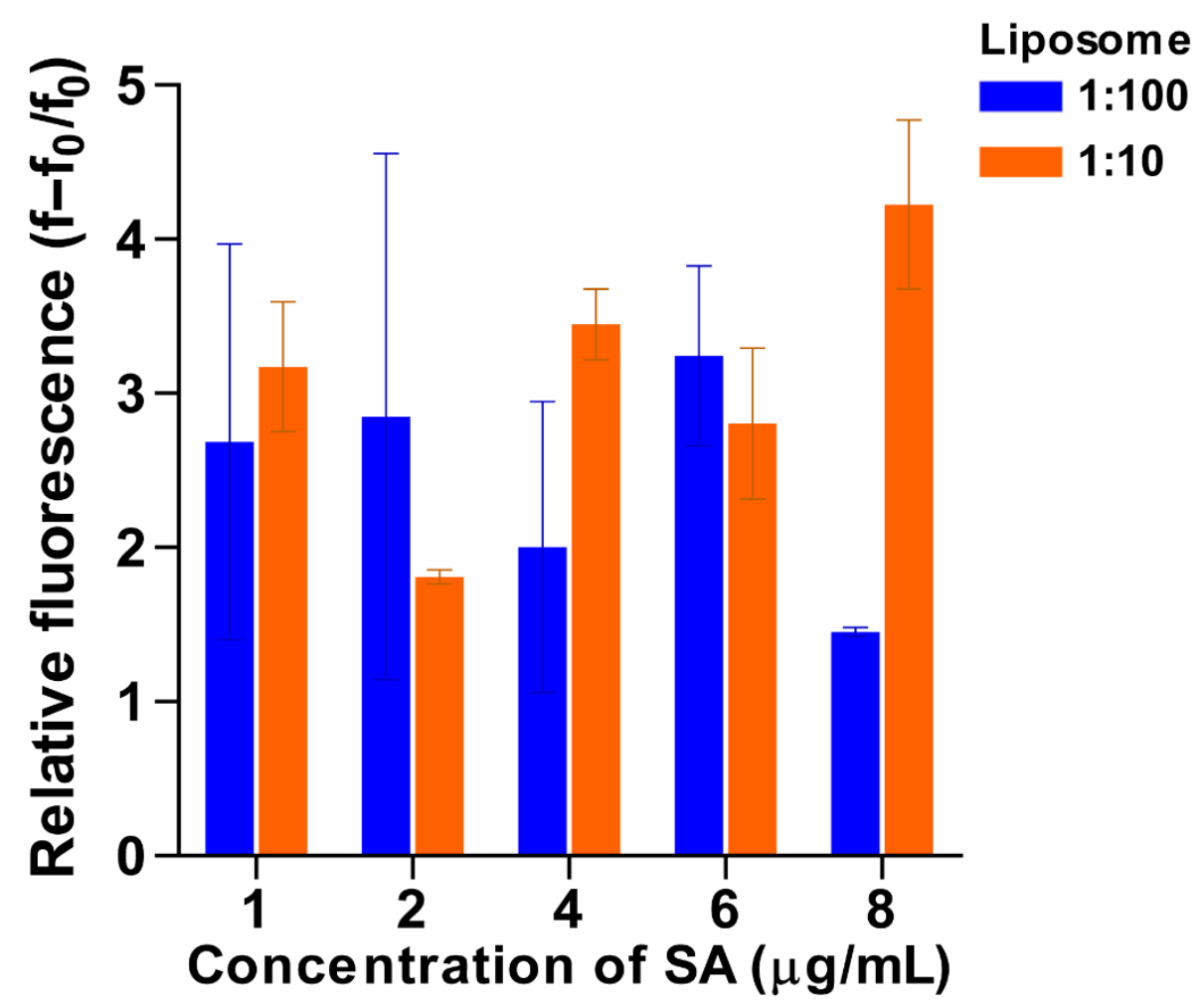

Figure 5. Effect of SA and liposome levels on cTnI assay. The relative emission at different concentrations of SA $(1,2,4,6$, and $8 \mu \mathrm{g} / \mathrm{mL})$ is plotted at two different dilutions of calcein liposome (1:100 and 1:10). The assay was performed at a fixed cTnI level of $80 \mathrm{ng} / \mathrm{mL}$, and $2 \mu \mathrm{g} / \mathrm{mL}$ of Biotin- $\mathrm{Ab}_{2}$. The error bars show the standard deviation of values for triplicate observations. (Two-way ANOVA test showed that there is statistically insignificant difference $(p=0.065)$ between the two assays and that the change in the relative fluorescence is insignificantly dependent $(p=0.710)$ on the concentration of SA in solution).

As the reproducibility of an immunoassay is an important criterion for practical applications, we conducted two independent batches of assays with triplicate runs. The assay was found to sense a wide range of $\mathrm{cTnI}$, exhibiting a good linear fit for the $\mathrm{cTnI}$ range $0-240 \mathrm{ng} / \mathrm{mL}(\mathrm{y}=0.0525 \mathrm{x})$ with a correlation coefficient of $\mathrm{R}^{2}=0.98$ (Figure 6, plot B). The assay response was found to have a high signal-to-noise ratio as compared to its reference assay values (Figure 6, plot $\mathrm{C}$ ) with a limit of detection (LOD) at $22.5 \mathrm{ng} / \mathrm{mL}$ determined as the minimum concentration of $\mathrm{cTnI}$ at which the mean $\left(\mathrm{f}-\mathrm{f}_{0}\right)$ values over all the replicates is larger than $\left(\mathrm{f}_{0}\right)$ by at least three standard deviations of the negative controls.

\subsubsection{Quantification of cTnI in Human Serum}

The next step was to assess the efficacy of the liposome-based fluorescent immunoassay in the quantification of the $\mathrm{cTnI}$ in the human serum. This is particularly important to determine the potential of applying the assay in practical clinical settings. Thus, we ran the assay on cTnI samples dissolved in undiluted human serum over a concentration range of cTnI 0-320 ng/mL, as per the optimized conditions used for cTnI in the BSA/PBS buffer system. The change in the relative fluorescence signal versus the change in the concentration of $\mathrm{CTnI}$ is depicted in Figure 6, plot A. The results show a linear relationship $(y=0.1468 x)$ of the relative fluorescence to the $c T n I$ levels in the serum with a very high correlation $\left(R^{2}=0.994\right)$. It was interesting to note that the cTnI-serum assay ended up in a higher response (Figure 6, plot $\mathrm{A}$ ) and even higher signal-to-noise ratio versus the reference as compared to the assay conduced in the BSA/PBS system (Figure 6, plot B). This can be attributed to the higher stability and solubility of cTnI in blood serum than in BSA/PBS [54]. Moreover, the assay has shown roughly around a 45-fold increased response 
for the cTnI-serum samples $(320 \mathrm{ng} / \mathrm{mL}$ ) versus those of the reference system (Figure 6, plot $D)$, which has all the components of the assay except that the wells were coated with BSA instead of $A b_{1}$. The limit of detection (LOD) of the assay was $6.5 \mathrm{ng} / \mathrm{mL}$ (determined as the minimum concentration of $\mathrm{CTnI}$ at which the mean $\left(\mathrm{f}-\mathrm{f}_{0}\right)$ values over all replicates is larger than $\left(\mathrm{f}_{0}\right)$ by at least three standard deviations of the negative controls), which is very close the normal level $(5 \mathrm{ng} / \mathrm{mL})$ cut-off in a patient's blood. Although our results presented a higher value of LOD than the previously reported assays [2,24,55-57], the assay was highly specific towards $\mathrm{cTnI}$ even in the presence of other interference proteins in the human serum and, more importantly, it has a wide linear dynamic range from right above the normal concentrations (LOD) of cTnI to $320 \mathrm{ng} / \mathrm{mL}$.

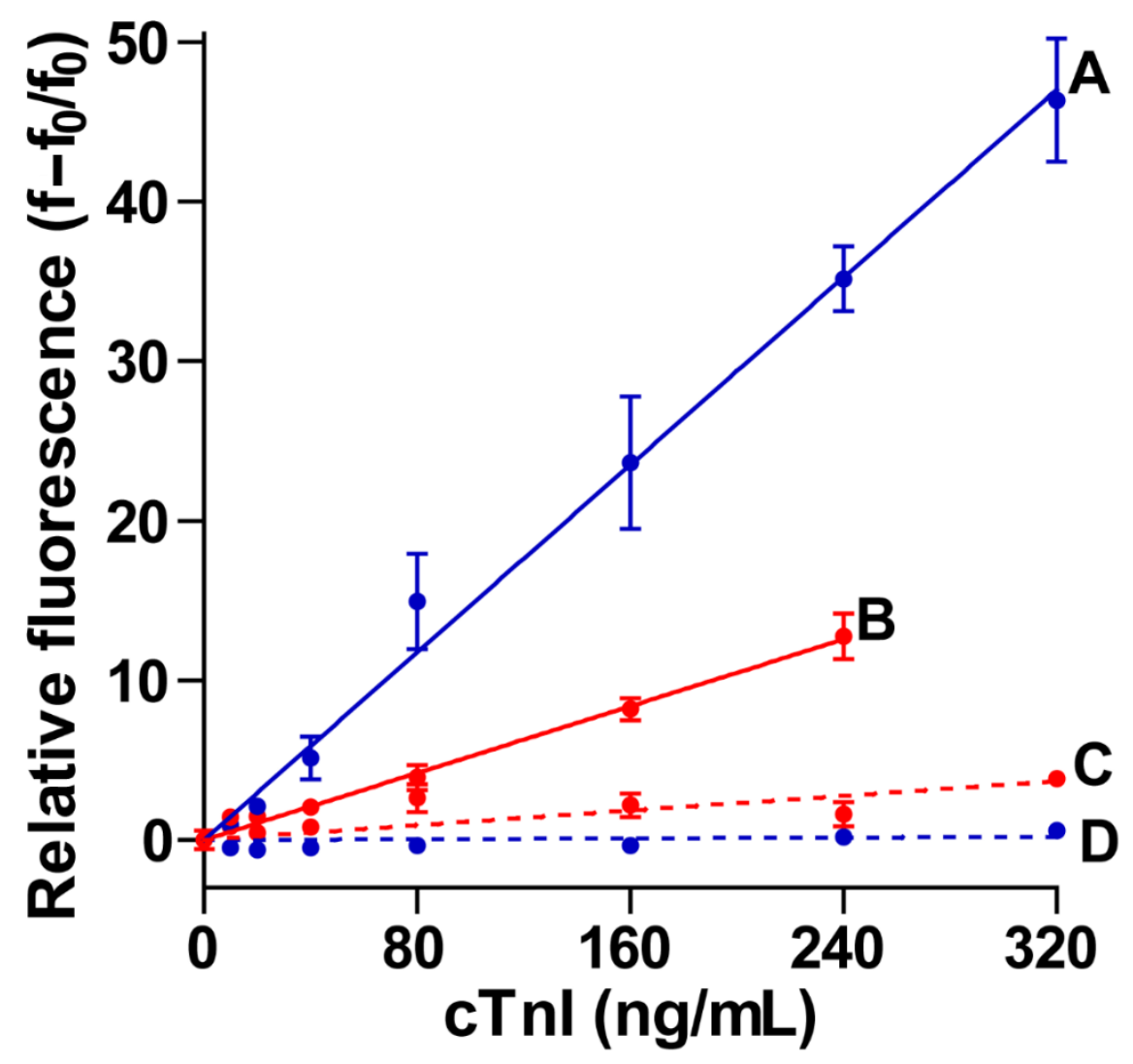

Figure 6. Comparison of the standardized assay (cTnI in BSA/human serum) with their reference assays. The relative emission at different levels of $\mathrm{cTnI}$ is plotted to a wide range of cTnI levels for (A) standardized immunoassay with cTnI-human serum and (B) standardized immunoassay with cTnI-BSA/PBS. C and D (dotted pattern plots) correspond to the reference assay for B and $A$, respectively. The reference assay indicates the standardized assay done in the absence of $A b_{1}$ (microplate wells coated with $2 \%$ BSA instead of capturing antibodies were used as assay platform). Error bars represent the standard deviation of two independent triplicates. (Two-way ANOVA test showed that there is statistically insignificant difference $(p<0.05)$ between the two independent assays for each of serum and PBS (for A, $p=0.533$; for $\mathrm{B}, p=0.795$ ), and the change in the relative fluorescence for each assay is significantly dependent (for $\mathrm{A}, p<0.001$; for $\mathrm{B}, p<0.001$ ) on the concentration of $\mathrm{CTnI}$ in solution).

\section{Materials and Methods}

\subsection{Chemicals/Materials}

1,2-Dipalmitoyl-sn-glycero-3-phosphocholine (DPPC), 1,2-Diastearoyl-sn-glycero-3phosphoethanolamine-N-[biotinyl(polyethylene glycol)-2000] (DSPE-PEG (2000) Biotin), Cholesterol and 1,2-diastearoyl-sn-glycero-3-phosphoethanolamine-N-[methoxy(polyethylene glycol)-2000] (DSPE-PEG (2000) and 200-nm polycarbonate filters were purchased from 
Avanti Polar Lipids, Inc., (Alabaster, AL, USA). Recombinant cTnI antigen and cTnI Antibodies [Anti-h cTnI 9705 SPTN-1, Anti-h cTnI 9703 SPTN-5 and Anti-h cTnI 9701 SPTN-5] from Medix Biochemica (Espoo, Finland). NHS-dPEG 4-biotin (Quanta Biodesign), Streptavidin from Streptomyces avidinii, H4522-Human serum type AB (Male) Maxisorp-NUNC immune plate (Thermo scientific, Waltham, MA, USA), PD-10 Sephadex TMG-25 M (GE Healthcare, Chicago, IL, USA), Calcein, SephadexTM-G-100 (GE-Healthcare), Dialysis tubing (CAROLINA Dialsis tubing, Molecular cut off 13,000, Burlington, NC, USA), Triton ${ }^{\mathrm{TM}}$ X-100, N,N-Dimethylformamide, PBS Tween ${ }^{\mathrm{TM}}-20$, phosphate buffered saline tablet, borate buffer ( $\mathrm{pH}$ 8.5), sodium bicarbonate buffer ( $\mathrm{pH}$ 9.4), and all other chemicals used for the study were of high analytical grade and were purchased from Sigma-Aldrich/Merck (Baden-Württemberg, Germany).

\subsection{Major Instrumentations}

The synthesis of liposomes was done with the help of Stuart Rotary evaporator. Sonication bath (Elma D-78224, Melrose Park, IL, USA) was used to get unilamellar vesicles (liposomes). Avanti Polar Lipids, Inc extruder was used for liposome-extrusion. The average radius and \% polydispersity of liposomes were examined by dynamic light scattering analysis (DLS) using Dyanopro Nano star Laser Photometer (Wyatt Technology Corp., Santa Barbara, CA, USA). Fluorescence emission measurements were done with the help of FLSP920 series of fluorescence spectrometers (Edinburgh Instruments Ltd., Livingston, UK). UV-Visible Spectrophotometer (EVOLUTION 60 S, Thermo Scientific) was used in Stewart assay for measuring the absorbance. FLUOstar Omega Plate reader from BMG LABTECH was employed for 96-well microtiter plate fluorescence measurements.

\subsection{Preparation of Dye (Calcein) Solution}

The study used calcein as a fluorescent dye considering its excellent fluorescent properties reported $[50,58]$. Calcein solution $(100 \mathrm{mM})$ was prepared in deionized water, and the $\mathrm{pH}$ of the solution was adjusted to 7.4 with $1 \mathrm{~N} \mathrm{NaOH}$.

\subsection{Synthesis of Calcein-Loaded Biotin-Liposome}

Nano liposomes were synthesized via the thin-film hydration method [45,46]. Briefly, the lipids formulation of $70 \mathrm{~mol} \%$ DPPC, $2.3 \mathrm{~mol} \%$ DSPE-Biotin, and $27.7 \%$ cholesterol were dissolved in chloroform $(4 \mathrm{~mL})$ by proper vortexing and sonication in a $100 \mathrm{~mL}$ round bottom flask. The lipid solution was carefully evaporated using a rotary evaporator at a low vacuum for the first $10 \mathrm{~min}$ with a rotation speed of $120 \mathrm{rpm}$ at $25^{\circ} \mathrm{C}$. The film was dried for another 50-60 min under a high vacuum. Liposomes were synthesized by hydration of the dry lipid film at $65{ }^{\circ} \mathrm{C}$ with $1.5 \mathrm{~mL}$ of calcein solution. Adequate vortexing and sonication were done during and after the hydration process. The large multilamellar vesicles of various sizes then passed through an extruder (Avanti Polar Lipids, Alabaster, AL, USA) $12-15$ times through $0.2-\mu \mathrm{m}$ polycarbonate membranes at $65^{\circ} \mathrm{C}$ to yield a homogeneous solution of unilamellar vesicles. The extruded biotin-conjugated liposomes were then purified by a double column elution chromatography using Sephadex G-100 resin (10 $\mathrm{mL}$ ), which was pre-equilibrated in PBS (7.4). The liposome was then stored at $4{ }^{\circ} \mathrm{C}$ for further use.

\subsection{Synthesis of Blocking Liposome}

Lipid film formation and hydration steps followed the same steps used for calceinbiotin liposome synthesis. The ratio of lipids and chloroform used was the same but DSPE-Biotin was replaced with DSPE-PEG and hydration of lipid thin film was done with $1.5 \mathrm{~mL}$ of PBS (pH 7.4). Adequate vortexing and sonication were done during and after the hydration process for nearly $10 \mathrm{~min}$. Blocking liposomes were purified by a spin column elution (PD-10 column), which was equilibrated with PBS (pH 7.4) at $3000 \mathrm{rpm}$ for $3 \mathrm{~min}$. 


\subsection{Characterization and Stability Analysis on Liposomes}

3.6.1. Dynamic Light Scattering (DLS) Measurements

The size range and \% polydispersity of Biotin-calcein liposomes were measured by DLS analysis. The liposome solutions were diluted around 100 times before DLS analysis. Regular DLS was done to monitor the size variation to confirm the stability of liposomes under the storage temperature of $4{ }^{\circ} \mathrm{C}$.

\subsubsection{Fluorescence Spectroscopy}

The fluorescence emission profiles of diluted calcein liposomes (1:10 ${ }^{5}$ in PBS) were measured using a fluorescence spectrometer. The emission spectra were taken in the absence and presence of 5\% Triton X-100 in Borate buffer ( $\mathrm{pH} 8.4$ ) at a scanning excitation wavelength of $490 \mathrm{~nm}$ and an emission wavelength range of 500-700 nm.

\subsubsection{Quantification of Lipid Content in Biotin Calcein Liposome}

The phospholipid concentration of the liposome solution was colorimetrically determined by Stewart assay as described in the literature [51]. Around $50 \mu \mathrm{L}$ of undiluted liposome fraction in a round bottom flask was placed in the rotary evaporator and dried up the suspended medium under vacuum. After drying, the flask was added with $1 \mathrm{~mL}$ of chloroform and was sonicated until a clear solution was formed. Varying volumes of solution from the flask were transferred to centrifuge tubes and made the total volume of solution to $2 \mathrm{~mL}$ with chloroform followed by the addition of $2 \mathrm{~mL}$ of ammonium ferrothiocyanate. The solutions were mixed properly and centrifuged for $10 \mathrm{~min}$ at $1000 \mathrm{rpm}$. The top dark layer was carefully discarded without touching the bottom layer and the clear chloroform bottom layer was moved to a quartz cuvette. The optical density of the cuvette solution was measured using an ultraviolet-visible spectrophotometer at $\lambda_{\max }=485 \mathrm{~nm}$ against chloroform-assay solution as blank.

\subsection{Conjugation of Biotin-Secondary Antibody}

The tethering of NHS-dPEG 4-biotin (around $57 \mathrm{mM}$ in DMF) to secondary/detection antibody $\left(\mathrm{Ab}_{2}\right)$ [pre dialyzed in PBS (pH 7.4)] was accomplished by reacting them in 20:1 volume ratio for $2 \mathrm{~h}$ at room temperature in a glass vial, a modified protocol reported earlier [55]. After conjugation, the excess unconjugated biotin was removed by spin column (equilibrated with PBS (pH 7.4) containing 0.01\% $\mathrm{NaN}_{3}$ ) elution done at $3000 \mathrm{rpm}$ for $3 \mathrm{~min}$. The Biotin- $\mathrm{Ab}_{2}$ solution was stored at $4{ }^{\circ} \mathrm{C}$ for further use.

\subsection{Standardization of Immunoassay Parameters}

\subsubsection{Choice of Assay Platform}

For the fluorescent assay, the $\mathrm{Ab}_{1}$ was covalently immobilized on the surface of activated microplates (Maxisorp NUNC 96 microplates, Thermo Fisher Scientific, Kamstrupvej, Denmark) through a covalent bond linkage of the activated carboxylate surface and an amine group of the antibody. The microplate wells provided the container for the successive addition and washing of assay reagents and an easy way for sensing and quantification of fluorescence intensity via microplate reader.

Preliminary standardization steps were performed to confirm the reproducibility and consistency of results while minimizing the time and cost to run the assay. Assay trials were carried out for selecting the best combinations of Capturing $\left(\mathrm{Ab}_{1}\right)$-Detection $\left(\mathrm{Ab}_{2}\right)$ cTnI-antibodies, optimizing the assay conditions, such as incubation time, the number of washings, dissolving buffer systems, capturing antibody concentrations, the concentration of Streptavidin, dilutions of liposomes, etc.

\subsubsection{Optimization of Capturing $\left(\mathrm{Ab}_{1}\right)$-Detection $\left(\mathrm{Ab}_{2}\right) \mathrm{cTnI}$-Antibodies Combination}

As Anti-h cTnI 9705 SPTN-1 and Anti-h cTnI 9703 SPTN-5 were selected as detection antibodies (conjugated with Biotin), their best complimentary antibodies, Anti-h cTnI 9701 SPTN-5, Anti-h cTnI 9703 SPTN-5, and Anti-h cTnI 9705 SPTN-5, were opted as 
capturing antibodies (for plate immobilization). Assay trials were carried out with different combinations of $\mathrm{Ab}_{1}-\mathrm{Ab}_{2}$ (Anti-h cTnI 9705-9703, 9703-9705, and 9701-9705). The $\mathrm{Ab}_{1}-$ antibodies were dissolved in bicarbonate buffer $(\mathrm{pH}$ 9.4) to get a final concentration of $2 \mu \mathrm{g} / \mathrm{mL}$. The assay was performed for all the mentioned combinations as per the protocol mentioned in Section 3.9, with cTnI levels of 0,50, 100, and $200 \mathrm{ng} / \mathrm{mL}$.

\subsubsection{Effect of Incubation Time}

The combination of Anti-h cTnI 9705 SPTN-1 and Anti-h cTnI 9703 SPTN-5 was found to be more efficient and was used for further assay optimization steps. Assay with wells coated at $5 \mu \mathrm{g} / \mathrm{mL}$ concentration of $\mathrm{Ab}_{1}$ (9705) (Section 3.9) was performed with reduced (half) incubation time to confirm whether the lower incubation assay reaction gives better results. cTnI and $\mathrm{Ab}_{2}$ - biotin incubated for $30 \mathrm{~min}$ and other parameters (SA, Blocking liposome, and calcein liposome) for $15 \mathrm{~min}$.

\subsubsection{Effect of Capturing Antibody $\left(\mathrm{Ab}_{1}\right)$ Concentration}

To fix the best coating concentration of $A b_{1}$, the assay was tried with three different $A b_{1}$ concentrations 2,4 , and $5 \mu \mathrm{g} / \mathrm{mL}$ and followed the normal assay steps as per Section 3.9.

\subsubsection{Effect of SA Concentration and Liposome Dilution}

To confirm the selected SA and calcein liposome concentration as best, two sets of assays were performed for a fixed cTnI level of $80 \mathrm{ng} / \mathrm{mL}$. The assay used 1:10 and 1:100 dilutions of liposomes (total lipid concentration $=10.1 \mathrm{mM}$ ) for SA levels of $1,2,4,6$, and $8 \mu \mathrm{g} / \mathrm{mL}$, maintaining the other conditions same as reported in Section 3.9.

\subsection{Standardized Assay Protocol (cTnI in Physiological Buffer System)}

For the standardized assay, $100 \mu \mathrm{L}$ of $\mathrm{Ab}_{1}$ (Anti-h cTnI 9705 SPTN-1 dissolved in bicarbonate buffer ( $\mathrm{pH}$ 9.4)) at $4 \mu \mathrm{g} / \mathrm{mL}$ were loaded into test wells, whereas $2 \% \mathrm{BSA} / \mathrm{PBS}$ $(300 \mu \mathrm{L})$ were coated in control wells. The plate was incubated at $4{ }^{\circ} \mathrm{C}$ overnight for maximum binding. After washing, the plate was blocked with $2 \%$ BSA $(300 \mu \mathrm{L})$ for $2 \mathrm{~h}$ at room temperature, shaking at $100 \mathrm{rpm}$. The solution was removed and wells were washed twice with PBST and one time with PBS and then tapped on tissues. Both control and $\mathrm{Ab}_{1}$-coated wells were coated with $100 \mu \mathrm{L}$ of varying concentrations of cTnI antigen $(0,10$, $20,40,80,160,240$, and $360 \mathrm{ng} / \mathrm{mL}$, diluted in BSA/PBS (1\%)) and incubated at $37^{\circ} \mathrm{C}$ for $1 \mathrm{~h}$, shaking at $100 \mathrm{rpm}$. The wells were washed 3 times with PBST $(300 \mu \mathrm{L})$ and tapped on tissues. $100 \mu \mathrm{L}$ of Biotin- $\mathrm{Ab}_{2}(2 \mu \mathrm{g} / \mathrm{mL}$, diluted in BSA/PBS (1\%) was loaded to all wells and incubated at $37^{\circ} \mathrm{C}$ for $1 \mathrm{~h}$, shaking at $100 \mathrm{rpm}$ followed by washing the plate 3 times with PBST $(300 \mu \mathrm{L})$. The wells were then incubated with $100 \mu \mathrm{L}$ of Streptavidin $(2 \mu \mathrm{g} / \mathrm{mL}$, diluted in $\mathrm{BSA} / \mathrm{PBS}(1 \%)$ at room temperature for $30 \mathrm{~min}$, shaking at $100 \mathrm{rpm}$, and washed 3 times with PBS $(300 \mu \mathrm{L})$. The wells were then blocked with $100 \mu \mathrm{L}$ of 1:100 times diluted blocking liposome (PBS) and allowed to incubate for $15 \mathrm{~min}$ at room temperature at same shaking conditions. After incubation, the solution was removed carefully and again incubated with calcein liposomes (100 $\mu \mathrm{L}$ of 1:100 times diluted in PBS) for $30 \mathrm{~min}$ at room temperature/shaking. Liposomes were removed and the plate was washed 5 times with PBS $(300 \mu \mathrm{L})$ and tapped on tissues after each wash. The fluorescence of dry wells was then measured with the help of FLUOstar Omega at an excitation wavelength of $490 \mathrm{~nm}$ and emission wavelength of $520 \mathrm{~nm}$ with a machine Gain of 1000. All the wells were then added with $100 \mu \mathrm{L}$ of $5 \%$ Triton X-100 (Borate buffer, $\mathrm{pH}$ 8.5) and allowed to mix for $10 \mathrm{~min}$ for the proper lysis of liposomes. The fluorescence emission from each well was measured at the same conditions as mentioned before. The relative increase in fluorescence intensity was found to be directly proportional to $\mathrm{cTnI}$ levels in the wells. The assays were conducted in week 4, 5, and 10 after preparation of the liposomes.

A control assay (reference) was conducted to analyze the sensitivity and signal noise (non-specific binding) effects on the assay. The assay was conducted in microtiter wells 
coated $2 \%$ BSA (instead of $\mathrm{Ab}_{1}$ ) with all other steps being the same and the standardized steps described above.

\subsection{0. cTnI Detection in Human Serum}

The performance of immunoassay was tested in human serum type $A B$ (male), spiked with different levels of cTnI. The efficacy and sensitivity of the assay were analyzed by comparing the results with those of the reference plate (assay conducted in $2 \%$ BSA coated plate). Same standardized assay steps were followed for the detection of cTnI in human serum. The assay was conducted in week 10 after preparation of the liposomes.

\subsection{Statistical Analysis}

Statistical significance was assessed using Microsoft Excel software. A $t$-test or a twoway ANOVA test were used to analyze the experimental data with statistically significant difference set at $p<0.05$. All error bars are a standard deviation from the mean values of three experiments.

\section{Conclusions}

In summary, we established a rapid and sensitive detection system for cardiac troponin I in the physiological buffer system and biological fluid (serum) by a liposome-based fluorescent amplification method. The calcein-loaded liposomes have featured reasonable stability and fluorescent properties over several weeks, which met the criteria of an efficient fluorophore nanocarrier for the assay. The proposed assay exhibited a noble analytical performance with dynamic linearity for human serum spiked with cTnI at a wide range of concentrations. In addition, it presented high selectivity to cTnI among other interfering proteins, such as BSA and other serum proteins. The wide range of concentration indicates that this immunoassay may have a promising potential for the direct application on non-diluted patients' serum samples since the LDR falls within the relevant clinical concentrations of $\mathrm{cTnI}$. This feature could potentially reduce the time of diagnosis and may provide information on the timing of MI incidents based on the level of $\mathrm{cTnI}$ in the blood using a single experiment without the need for repeated testing. Yet, further optimization studies with regard to assay time and a change in the immobilization platform would be required to develop the assay to the level of a point-of-care kit. Besides, developing such a kit for clinical settings requires further validation and testing with clinical samples of patients' serum and benchmarking against other developed kits in the market.

Author Contributions: Conceptualization, M.H.A.-S.; methodology, M.H.A.-S. and R.R.; resources, M.H.A.-S.; data curation, M.H.A.-S. and R.R.; writing — original draft preparation, R.R.; writingreview and editing, M.H.A.-S. and R.R.; visualization, M.H.A.-S. supervision, M.H.A.-S.; project administration, M.H.A.-S.; funding acquisition, M.H.A.-S. All authors have read and agreed to the published version of the manuscript.

Funding: Funding was provided by the American University of Sharjah, UAE (grant \# BBRI18-CAS05) and, in part, by the Open Access Program at the American University of Sharjah, UAE (grant \# OAPCAS-1110-C00009).

Institutional Review Board Statement: De-identified human serum samples were purchased from Sigma-Aldrich/Merck (Germany) through its local representative (LABCO, UAE) and in accordance with AUS Supply Chain Policy. The Office of Research at the American University of Sharjah determined that these samples are not subject to IRB review because the samples do not have any identification information.

Informed Consent Statement: Not applicable.

Data Availability Statement: Not applicable. 
Acknowledgments: The authors acknowledge the technical and logistics support of BCE Department, and the Office of Research at the American University of Sharjah, UAE. We thank Ghaleb Husseini and the entire team of Drug Delivery Laboratory at American University of Sharjah, UAE for their excellent support. RR acknowledges the support of the 2nd Forum for Women in Research (QUWA) at University of Sharjah, UAE.

Conflicts of Interest: The authors declare no conflict of interest.

Sample Availability: Samples of the compounds are not available from the authors.

Disclosure: This paper represents the opinions of the authors and does not mean to represent the position or opinions of the American University of Sharjah.

\section{References}

1. Diastolic Heart Failure; Smiseth, O.A.; Tendera, M. (Eds.) Springer: London, UK, 2008. [CrossRef]

2. Cai, Y.; Kang, K.; Li, Q.; Wang, Y.; He, X. Rapid and Sensitive Detection of Cardiac Troponin I for Point-of-Care Tests Based on Red Fluorescent Microspheres. Molecules 2018, 23, 1102. [CrossRef]

3. Al-Shamsi, S.; Regmi, D.; Govender, R.D. Incidence of Cardiovascular Disease and Its Associated Risk Factors in At-Risk Men and Women in the United Arab Emirates: A 9-Year Retrospective Cohort Study. BMC Cardiovasc. Disord. 2019, 19, 148. [CrossRef] [PubMed]

4. WHO Global Status Report on Noncommunicable Diseases 2014. Available online: http://apps.who.int/iris/bitstream/handle/ 10665/148114/9789241564854_eng.pdf;jsessionid=FB5EFBD8AF0D2FAAF7F31E5BFFE2826F?sequence=1 (accessed on 15 July 2021).

5. King, M.; Kingery, J.; Casey, B. Diagnosis and Evaluation of Heart Failure. Am. Fam. Physician 2012, 85, 1161-1168. [PubMed]

6. Deshpande, A.; Birnbaum, Y. ST-Segment Elevation: Distinguishing ST Elevation Myocardial Infarction from ST Elevation Secondary to Nonischemic Etiologies. World J. Cardiol. 2014, 6, 1067-1079. [CrossRef]

7. Taherinia, A.; Ahmadi, K.; Bahramian, M.; Khademhosseini, P.; Taleshi, Z.; Maghsoudi, M.; Sattarzadeh Badkoubeh, R.; Talebian, M.T.; Rezaee, M. Diagnostic Value of Standard Electrocardiogram in Acute Right Ventricular Myocardial Infarction. Eur. J. Transl. Myol. 2019, 29, 130-135. [CrossRef] [PubMed]

8. Luo, J.; Li, S.; Xu, M.; Guan, M.; Yang, M.; Ren, J.; Zhang, Y.; Zeng, Y. Real-Time Detection of Cardiac Troponin I and Mechanism Analysis of AlGaAs/GaAs High Electron Mobility Transistor Biosensor. AIP Adv. 2020, 10, 115205. [CrossRef]

9. Sharma, S. Cardiac Troponins. J. Clin. Pathol. 2004, 57, 1025-1026. [CrossRef]

10. Bozdogan, A.; El-Kased, R.F.; Jungbluth, V.; Knoll, W.; Dostalek, J.; Kasry, A. Development of a Specific Troponin I Detection System with Enhanced Immune Sensitivity Using a Single Monoclonal Antibody. R. Soc. Open Sci. 2020, 7, 200871. [CrossRef]

11. Guy, M.J.; Chen, Y.-C.; Clinton, L.; Zhang, H.; Zhang, J.; Dong, X.; Xu, Q.; Ayaz-Guner, S.; Ge, Y. The Impact of Antibody Selection on the Detection of Cardiac Troponin I. Clin. Chim. Acta 2013, 420, 82-88. [CrossRef]

12. Katrukha, I.A.; Katrukha, A.G. Myocardial Injury and the Release of Troponins I and T in the Blood of Patients. Clin. Chem. 2021, 67, 124-130. [CrossRef] [PubMed]

13. Han, X.; Li, S.; Peng, Z.; Othman, A.M.; Leblanc, R. Recent Development of Cardiac Troponin I Detection. ACS Sens. 2016, 1, 106-114. [CrossRef]

14. Mahajan, V.S.; Jarolim, P. How to Interpret Elevated Cardiac Troponin Levels. Circulation 2011, 124, 2350-2354. [CrossRef]

15. Amundson, B.E.; Apple, F.S. Cardiac Troponin Assays: A Review of Quantitative Point-of-Care Devices and Their Efficacy in the Diagnosis of Myocardial Infarction. Clin. Chem. Lab. Med. CCLM 2015, 53, 665-676. [CrossRef] [PubMed]

16. Park, K.C.; Gaze, D.C.; Collinson, P.O.; Marber, M.S. Cardiac Troponins: From Myocardial Infarction to Chronic Disease. Cardiovasc. Res. 2017, 113, 1708-1718. [CrossRef] [PubMed]

17. Jaffe, A.S.; Babuin, L.; Apple, F.S. Biomarkers in Acute Cardiac Disease: The Present and the Future. J. Am. Coll. Cardiol. 2006, 48, 1-11. [CrossRef] [PubMed]

18. Pleister, A.; Selemon, H.; Elton, S.M.; Elton, T.S. Circulating miRNAs: Novel biomarkers of acute coronary syndrome? Biomark. Med. 2013, 7, 287-305. [CrossRef] [PubMed]

19. Mascia, G.; Pescetelli, F.; Baldari, A.; Gatto, P.; Seitun, S.; Sartori, P.; Pieroni, M.; Calò, L.; Della Bona, R.; Porto, I. Interpretation of Elevated High-Sensitivity Cardiac Troponin I in Elite Soccer Players Previously Infected by Severe Acute Respiratory Syndrome Coronavirus 2. Int. J. Cardiol. 2021, 326, 248-251. [CrossRef]

20. Airaksinen, K.E.J. Cardiac Troponin Release After Endurance Exercise: Still Much to Learn. J. Am. Heart Assoc. 2020,9 , e015912. [CrossRef] [PubMed]

21. Agewall, S.; Giannitsis, E.; Jernberg, T.; Katus, H. Troponin Elevation in Coronary vs. Non-Coronary Disease. Eur. Heart J. 2011, 32, 404-411. [CrossRef] [PubMed]

22. Chuang, A.M.-Y.; Nguyen, M.T.; Kung, W.-M.; Lehman, S.; Chew, D.P. High-Sensitivity Troponin in Chronic Kidney Disease: Considerations in Myocardial Infarction and Beyond. Rev. Cardiovasc. Med. 2020, 21, 191-203. [CrossRef] [PubMed]

23. Long, B.; Long, D.A.; Tannenbaum, L.; Koyfman, A. An Emergency Medicine Approach to Troponin Elevation Due to Causes Other than Occlusion Myocardial Infarction. Am. J. Emerg. Med. 2020, 38, 998-1006. [CrossRef] [PubMed] 
24. Radha, R.; Shahzadi, S.K.; Al-Sayah, M.H. Fluorescent Immunoassays for Detection and Quantification of Cardiac Troponin I: A Short Review. Molecules 2021, 26, 4812. [CrossRef]

25. Jiang, H.; Zhu, J.; Liu, W.; Cao, F. High-Sensitivity Cardiac Troponins I Sandwich Assay by Immunomagnetic Microparticle and Quantum Dots. Front. Lab. Med. 2017, 1, 107-113. [CrossRef]

26. Upasham, S.; Tanak, A.; Prasad, S. Cardiac Troponin Biosensors: Where Are We Now? Adv. Health Care Technol. 2018, 4, 1-13. [CrossRef]

27. Haushalter, K.J.; Vetcha, S.; Haushalter, R.C. Multiplex Flow Assays. ACS Omega 2016, 1, 586-599. [CrossRef] [PubMed]

28. Ju, H.; Zhang, X.; Wang, J. NanoBiosensing: Principles, Development and Application; Biological and Medical Physics, Biomedical Engineering; Springer: New York, NY, USA, 2011; ISBN 978-1-4419-9621-3.

29. Lee, K.H.; Park, H.; Hwang, M. Immunomagnetic Nanoparticle-Based Assays for Detection of Biomarkers. Int. J. Nanomed. 2013, 8, 4543-4552. [CrossRef]

30. Mayilo, S.; Kloster, M.A.; Wunderlich, M.; Lutich, A.; Klar, T.A.; Nichtl, A.; Kürzinger, K.; Stefani, F.D.; Feldmann, J. Long-Range Fluorescence Quenching by Gold Nanoparticles in a Sandwich Immunoassay for Cardiac Troponin T. Nano Lett. 2009, 9, 4558-4563. [CrossRef]

31. Singal, S.; Srivastava, A.K.; Gahtori, B. Rajesh Immunoassay for Troponin I Using a Glassy Carbon Electrode Modified with a Hybrid Film Consisting of Graphene and Multiwalled Carbon Nanotubes and Decorated with Platinum Nanoparticles. Microchim. Acta 2016, 183, 1375-1384. [CrossRef]

32. Zhu, J.; Zou, N.; Zhu, D.; Wang, J.; Jin, Q.; Zhao, J.; Mao, H. Simultaneous Detection of High-Sensitivity Cardiac Troponin I and Myoglobin by Modified Sandwich Lateral Flow Immunoassay: Proof of Principle. Clin. Chem. 2011, 57, 1732-1738. [CrossRef]

33. Xu, W.; Wang, L.; Zhang, R.; Sun, X.; Huang, L.; Su, H.; Wei, X.; Chen, C.-C.; Lou, J.; Dai, H.; et al. Diagnosis and Prognosis of Myocardial Infarction on a Plasmonic Chip. Nat. Commun. 2020, 11, 1654. [CrossRef]

34. Zhang, J.; Kruss, S.; Hilmer, A.J.; Shimizu, S.; Schmois, Z.; De La Cruz, F.; Barone, P.W.; Reuel, N.F.; Heller, D.A.; Strano, M.S. A Rapid, Direct, Quantitative, and Label-Free Detector of Cardiac Biomarker Troponin T Using Near-Infrared Fluorescent Single-Walled Carbon Nanotube Sensors. Adv. Healthc. Mater. 2014, 3, 412-423. [CrossRef] [PubMed]

35. Cho, J.-H.; Kim, M.-H.; Mok, R.-S.; Jeon, J.-W.; Lim, G.-S.; Chai, C.-Y.; Paek, S.-H. Two-Dimensional Paper Chromatography-Based Fluorescent Immunosensor for Detecting Acute Myocardial Infarction Markers. J. Chromatogr. B 2014, 967, 139-146. [CrossRef] [PubMed]

36. Rodenko, O.; Eriksson, S.; Tidemand-Lichtenberg, P.; Troldborg, C.P.; Fodgaard, H.; van Os, S.; Pedersen, C. High-Sensitivity Detection of Cardiac Troponin I with UV LED Excitation for Use in Point-of-Care Immunoassay. Biomed. Opt. Express 2017, 8, 3749. [CrossRef]

37. Lee, S.; Kang, S.H. Quenching Effect on Gold Nano-Patterned Cardiac Troponin I Chip by Total Internal Reflection Fluorescence Microscopy. Talanta 2013, 104, 32-38. [CrossRef] [PubMed]

38. Lopez-Calle, E.; Espindola, P.; Spinke, J.; Lutz, S.; Nichtl, A.; Tgetgel, A.; Herbert, N.; Marcinowski, M.; Klepp, J.; Fischer, T.; et al. A New Immunochemistry Platform for a Guideline-Compliant Cardiac Troponin T Assay at the Point of Care: Proof of Principle. Clin. Chem. Lab. Med. CCLM 2017, 55, 1798-1804. [CrossRef] [PubMed]

39. Tang, L.; Casas, J.; Venkataramasubramani, M. Magnetic Nanoparticle Mediated Enhancement of Localized Surface Plasmon Resonance for Ultrasensitive Bioanalytical Assay in Human Blood Plasma. Anal. Chem. 2013, 85, 1431-1439. [CrossRef] [PubMed]

40. Tan, Y.; Wang, Y.; Li, M.; Ye, X.; Wu, T.; Li, C. Enhanced Photoelectrochemical Immunosensing of Cardiac Troponin I Based on Energy Transfer between N-Acetyl-L-Cysteine Capped CdAgTe Quantum Dots and Dodecahedral Au Nanoparticles. Biosens. Bioelectron. 2017, 91, 741-746. [CrossRef]

41. Wang, Y.; Yang, Y.; Chen, C.; Wang, S.; Wang, H.; Jing, W.; Tao, N. One-Step Digital Immunoassay for Rapid and Sensitive Detection of Cardiac Troponin I. ACS Sens. 2020, 5, 1126-1131. [CrossRef]

42. Braga, F.; Aloisio, E.; Panzeri, A.; Nakagawa, T.; Panteghini, M. Analytical Validation of a Highly Sensitive Point-of-Care System for Cardiac Troponin I Determination. Clin. Chem. Lab. Med. CCLM 2019, 58, 138-145. [CrossRef]

43. Awad, N.S.; Paul, V.; Mahmoud, M.S.; Al Sawaftah, N.M.; Kawak, P.S.; Al Sayah, M.H.; Husseini, G.A. Effect of Pegylation and Targeting Moieties on the Ultrasound-Mediated Drug Release from Liposomes. ACS Biomater. Sci. Eng. 2020, 6, 48-57. [CrossRef]

44. Ahmed, S.E.; Moussa, H.G.; Martins, A.M.; Abbas, Y.; Al-Sayah, M.H.; Husseini, G.A. Factors Affecting the Acoustic In Vitro Release of Calcein from PEGylated Liposomes. J. Nanosci. Nanotechnol. 2019, 19, 6899-6906. [CrossRef]

45. Salkho, N.M.; Paul, V.; Kawak, P.; Vitor, R.F.; Martins, A.M.; Al Sayah, M.; Husseini, G.A. Ultrasonically Controlled EstroneModified Liposomes for Estrogen-Positive Breast Cancer Therapy. Artif. Cells Nanomed. Biotechnol. 2018, 46, 462-472. [CrossRef] [PubMed]

46. Ahmed, S.E.; Moussa, H.G.; Martins, A.M.; Al-Sayah, M.H.; Husseini, G.A. Effect of PH, Ultrasound Frequency and Power Density on the Release of Calcein from Stealth Liposomes. Eur. J. Nanomed. 2016, 8. [CrossRef]

47. Elamir, A.; Ajith, S.; Sawaftah, N.A.; Abuwatfa, W.; Mukhopadhyay, D.; Paul, V.; Al-Sayah, M.H.; Awad, N.; Husseini, G.A. Ultrasound-Triggered Herceptin Liposomes for Breast Cancer Therapy. Sci. Rep. 2021, 11, 7545. [CrossRef]

48. Ben Daya, S.M.; Paul, V.; Awad, N.S.; Al Sawaftah, N.M.; Al Sayah, M.H.; Husseini, G.A. Targeting Breast Cancer Using Hyaluronic Acid-Conjugated Liposomes Triggered with Ultrasound. J. Biomed. Nanotechnol. 2021, 17, 90-99. [CrossRef]

49. Awad, N.S.; Paul, V.; Al-Sayah, M.H.; Husseini, G.A. Ultrasonically Controlled Albumin-Conjugated Liposomes for Breast Cancer Therapy. Artif. Cells Nanomed. Biotechnol. 2019, 47, 705-714. [CrossRef] 
50. Maherani, B.; Arab-Tehrany, E.; Kheirolomoom, A.; Geny, D.; Linder, M. Calcein Release Behavior from Liposomal Bilayer; Influence of Physicochemical/Mechanical/Structural Properties of Lipids. Biochimie 2013, 95, 2018-2033. [CrossRef] [PubMed]

51. AlSawaftah, N.M.; Awad, N.S.; Paul, V.; Kawak, P.S.; Al-Sayah, M.H.; Husseini, G.A. Transferrin-Modified Liposomes Triggered with Ultrasound to Treat HeLa Cells. Sci. Rep. 2021, 11, 11589. [CrossRef] [PubMed]

52. Filatov, V.; Katrukha, A.; Bereznikova, A.; Esakova, T.; Bulargina, T.; Kolosova, O.; Severin, E.; Gusev, N. Epitope Mapping of Anti-Troponin I Monoclonal Antibodies. IUBMB Life 1998, 45, 1179-1187. [CrossRef]

53. Vylegzhanina, A.V.; Kogan, A.E.; Katrukha, I.A.; Antipova, O.V.; Kara, A.N.; Bereznikova, A.V.; Koshkina, E.V.; Katrukha, A.G. Anti-Cardiac Troponin Autoantibodies Are Specific to the Conformational Epitopes Formed by Cardiac Troponin I and Troponin $\mathrm{T}$ in the Ternary Troponin Complex. Clin. Chem. 2017, 63, 343-350. [CrossRef]

54. Labugger, R.; Organ, L.; Collier, C.; Atar, D.; Van Eyk, J.E. Extensive Troponin I and T Modification Detected in Serum From Patients with Acute Myocardial Infarction. Circulation 2000, 102, 1221-1226. [CrossRef] [PubMed]

55. Lim, G.-S.; Seo, S.-M.; Paek, S.-H.; Kim, S.-W.; Jeon, J.-W.; Kim, D.-H.; Cho, I.-H.; Paek, S.-H. Chemiluminometric Immunosensor for High-Sensitivity Cardiac Troponin I Employing a Polymerized Enzyme Conjugate as a Tracer. Sci. Rep. 2015, 5, 14848. [CrossRef] [PubMed]

56. Natarajan, S.; Jayaraj, J.; Prazeres, D.M.F. A Cellulose Paper-Based Fluorescent Lateral Flow Immunoassay for the Quantitative Detection of Cardiac Troponin I. Biosensors 2021, 11, 49. [CrossRef] [PubMed]

57. Hemmig, E.; Temiz, Y.; Gökçe, O.; Lovchik, R.D.; Delamarche, E. Transposing Lateral Flow Immunoassays to Capillary-Driven Microfluidics Using Self-Coalescence Modules and Capillary-Assembled Receptor Carriers. Anal. Chem. 2020, 92, 940-946. [CrossRef]

58. Deng, W.; Chen, W.; Clement, S.; Guller, A.; Zhao, Z.; Engel, A.; Goldys, E.M. Controlled Gene and Drug Release from a Liposomal Delivery Platform Triggered by X-Ray Radiation. Nat. Commun. 2018, 9, 2713. [CrossRef] 